\section{Social insurance, mutualistic insurance and genetic information}

\author{
Eli Feiring (i)
}

While a number of jurisdictions internationally prohibit insuring companies to be able to use genetic information in their risk classification, a voluntary code of practice permits insurers the limited use of predictive genetic test results in the UK.

Jonathan Pugh ${ }^{1}$ offers a pluralist justicebased argument in support of the UK practice. Pugh's position is developed to avoid what he sees as flaws with the current debate on insurers' access to genetic information, including (1) an alleged reliance on idealised assumptions about the predictive power of genetic test results, (2) revisionary implications for the provision of insurance suggested in the debate and (3) failings of commentators to engage adequately with a conception of justice that undergirds the status quo approach in the UK.

Pugh suggests that a quasi-libertarian approach to justice is implicit within the terms of the present Code and should be phrased as a principle of equity. Further, he argues that basic egalitarian and noncomparative concerns should be captured in broad principles: equal access and need. This leaves him with three principles that should be balanced in order to guide protection insurance policy.

When the argument is applied to review the current iteration of the code, Pugh demonstrates the argument's critical potential. He illustrates how the quasi-libertarian interpretation seems to dominate the implementation of the code. Hence, the principle of equity justifies the use of genetic information selectively rather than to guard against general adverse selection. Pugh criticises this application of the principle.

While I am largely sympathetic with Pugh's intention to engage with a conception of justice that underpins the UK approach, I am sceptical of his view on genetic exceptionalism. If insurers are permitted to use non-genetic medical risk information, there is no reason to forestall the use of predictive genetic information, as Pugh suggests. The implication may be that the quasi-libertarian approach to justice gains dominance.

Correspondence to Dr Eli Feiring, Department of Health Management and Health Economics, University of Oslo, Oslo 0316, Norway; eli.feiring@medisin.uio.no

\section{METHOD: AN ENGAGED VIEW}

Normative disagreement can be dealt with in different ways. Some argue in favour of the method of applied philosophy. Foundational and ideal principles will guide us to make decisions that best approximate the theory. However, political theorising often make use of false or unlikely conditional assumptions about motivation, behaviour and social structures that do not apply effortlessly to real-world circumstances. Indeed, a number of theorists have pointed out that theorising involving idealisation rather than mere abstractions from real-world complexities cannot be brought to bear on non-ideal problems. ${ }^{23}$ Ideal theorising turns out counterproductive and fails to motivate agents and to inform political decisions. In short: it fails to be action guiding. In response to such worries, we may turn to non-ideal theory, formulating principles of policy and regulation, given certain assumptions about what individuals and institutions are actually likely to do.

Alternatively, moral disagreement may rather be reviewed using the method of engaged or constructive philosophy. ${ }^{4} 5$ This method asks us to identify relevant values in the context of a specific problem and to work through a series of steps so that agreement can be made in a given case.

Pugh seems to favour this latter option. There is, however, an inbuilt conservatism in the process, which may support the status quo. ${ }^{4}$ This challenge is worth our attention.

\section{GENETIC INJUSTICE IN HEALTHCARE PROVISION: A PRAGMATIC VIEW}

Healthcare systems like the NHS, which are universal, tax-financed and needbased, are typically founded on values and principles such as equal access, equity and solidarity. If we take these constitutive values seriously, differential treatment in provision of healthcare on the basis of genetic information is unjust.

However, as Pugh rightly points out, there may be several other values that are relevant to the debate on access to mutualistic insurance, including health or critical illness schemes. These values should be identified and evaluated. For example, in societies that value freedom to access advantages that accrue to individuals by virtue of their health status, mutualistic health insurance is often established as a supplement providing better access to high-quality services, a lump sum in case of critical illness, etc.

A system of mutualistic insurance is stable only under conditions of sufficient informational symmetry. Thus, the insurer should have roughly the same riskrelevant information about the insured as the insured has herself (the principle of uberrima fides). Moreover, the insured should pay a premium commensurate with the risks she brings into the insurance pool (the principle of actuarial fairness). ${ }^{6}$

Regulating access to genetic information introduces an informational asymmetry between the insurer and the insured and, consequently, undermine the principle of actuarial fairness. Given a future where genetic testing is widespread and tests are developed with significant actuarial value, restricting insurers' access to genetic test results may lead to social inefficiencies and inequities in the market. ${ }^{7}$ Consequently, restricting insurers' access to riskrelevant information, including genetic information, is difficult to defend. ${ }^{6}$ Voluntary supplementary insurance should operate on commercial principles, without differential treatment of genetic and nongenetic information.

However, the legitimacy of such arrangements is crucially dependent on the provision of necessary care within the social health insurance scheme. Differentiation in premiums of voluntary supplementary insurance on the basis of medical risk information, including genetic information, is acceptable only if citizens are provided sufficient healthcare on an equal footing.

Contributors EF is the only author of this article.

Funding The authors have not declared a specific grant for this research from any funding agency in the public, commercial or not-for-profit sectors.

Competing interests None declared.

Patient consent for publication Not required.

Provenance and peer review Commissioned; internally peer reviewed.

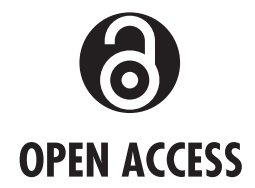

Open access This is an open access article distributed in accordance with the Creative Commons Attribution Non Commercial (CC BY-NC 4.0) license, which permits others to distribute, remix, adapt, build upon this work non-commercially, and license their derivative works on 
different terms, provided the original work is properly cited, appropriate credit is given, any changes made indicated, and the use is non-commercial. See: http:// creativecommons.org/licenses/by-nc/4.0/.

(C) Author(s) (or their employer(s)) 2021. Re-use permitted under CC BY-NC. No commercial re-use. See rights and permissions. Published by BMJ.

\section{D) Check for updates}

To cite Feiring E. J Med Ethics 2021;47:486-487.

Received 24 May 2021

Accepted 26 May 2021

Published Online First 14 June 2021

\section{(P) Linked}

- http://dx.doi.org/10.1136/medethics-2020-106913

J Med Ethics 2021;47:486-487.

doi:10.1136/medethics-2021-107542

\section{ORCID iD}

Eli Feiring http://orcid.org/0000-0001-5280-1051

\section{REFERENCES}

1 Pugh J. Genetic information, insurance and a pluralistic approach to justice. J Med Ethics 2021;47:473-9.
2 Valentini L, Ideal vs. Non-Ideal theory: a conceptual MAP. Political Compass 2012;7(9):654-64.

3 Hamlin A, Stemplowska Z. Theory, ideal theory and the theory of ideals. Political Studies Review 2012;10(1):48-62.

4 Wolff J. Method in Philosophy and Public Policy: Applied Philosophy versus Engaged Philosophy. In: Lever A P, ed. The Routledge hand book of ethics and public policy. London: Routledge, 2018.

5 Wood M. Engaged political science. Political Studies Review 2020;18(2):245-62.

6 Feiring E. Reassessing insurers' access to genetic information: genetic privacy, ignorance, and injustice. Bioethics 2009;23(5):300-10.

7 Hoel M, Iversen T. Genetic testing when there is a mix of compulsory and voluntary health insurance. $J$ Health Econ 2002:21(2):253-70. 